QIJIS: Qudus International Journal of Islamic Studies

Volume 6, Issue 2, Agustus 2018

\title{
NEO-PATRIARCHY AND THE PROBLEM OF THE ARAB CRISIS: A CRITICAL STUDY ON HISHAM SHARABI'S WORKS
}

\author{
Yoyo \\ Universitas Ahmad Dahlan, Yogyakarta, Indonesia \\ yoyo@bsa.uad.ac.id
}

\begin{abstract}
The paper tries to elaborate the ideas of Hisham Sharabi on Neo-patriarchy culture and its relevance to the current situations. He perceived that Neo-patriarchy as one of main causes of the Arab crisis. He also argued that the Arab societies, in general, did not adopt modernism in its real form. Therefore, instead of transforming into modern society, they turned into "distorted modernism." The data of this research particularly are Sharabi's works that were published during 1980s as crucial period of his intellectual journey. The paper found three major conclusions on neo-patriarchy culture postulated by Sharabi: 1) neopatriarchy culture is the real form of Arab's failure in transforming its societies into modern one as reflected in authoritarian political system, economic dependent and social-political fragmentation; 2) criticism is preconditions for modern Arab societies' transformation. One of the efforts to achieve real modernism, according to Sharabi, is to deconstruct some distorted definitions of democracy, civil society, etc., and build fresh meaning of the terms.
\end{abstract}

Keywords:Neo-patriarchy, Arab crisis, distorted modernism, Arab criticism. 


\section{A. Introduction}

Recently, we have witnessed various social, political, economic, and even humanitarian tragedies in the form of continuing civil wars in the Middle East and the Arab World in particular. The Arab states, since the collapse of the Ottoman Empire to the independent from European colonialism, and even turned into modern nation states, faced many crucial issues. The issue of authoritarian political leadership, socioeconomic imbalances, clashes between tradition and modernity, women's position, and other crucial issues have never seemed to be solved and even seem to be more complex.

Arab intellectual responses to the crisis experienced by Arab society can be traced to the era of Islamic modernism or whatso-called Nahda era. It was started from the idea of PanIslamism of Jamal al-Din al-Afghani (1838-1897), followed by the idea of modernization of Islamic education by Muhammad Abduh (1849-1905) and the call for Islamic purification promoted by Rashid Ridha (1865-1935) which also stressed on the importance of modern progress (Hourani, 1962). The blend of Islamic interpretation as an answer to the modernism exhaled by the West continued until the end of the $20^{\text {th }}$ century. Ultimately, the idea of Islamic modernism with its variants must end with the defeat of the Arab-Israeli war in 1967. After the defeat, the common enemy of Islam was no longer the West but the Muslim itself (Abu-Rabi', 2004; Yoyo et al., 2012). This critical self-reflection is than called self-criticism or Naqd an-Nafs.

Therefore, the problem of the crisis in the Arab world can be seen as the effect of powerlessness of the Arab society in criticizing their crucial problems. One of criticisms expressed by an Arab thinker sees that one of the main causes of the failure of the Arab society in achieving the real movement of modernism is the strengthening of patriarchal culture. This idea was developed by a Palestinian thinker, Hisham Sharabi, a prominent Arab intellectual and Professor Emeritus of History and Umar al-Mukhtar Chair 
of Arab Culture at Georgetown University. The paper seeks to elaborate Sharabi's thought about the causes of the crisis faced by the Arab nations and its reflective solutions. The urgency of the paper lies on an attempt to highlight one perspective on the Arab crisis from genuine Arab intellectual. In particular, the paper tries to elaborate important works of Hisham Sharabi on Neopatriarchy in reading the context of modern Arab world before and after the Arab Spring.

\section{B. Discussion}

\section{Arab Crisis Through the Intellectual Perspectives}

This section explores priority issues that the Arab intellectuals consider them being crucial and critical issues. The Arab intellectuals have certain priorities based on a particular era. In the era of renaissance or Nahda era, for example, the Arab intellectuals saw that the Arab crisis and problems as summarized by Kassab (2010, pp. 21-22) rested in the following issues:

a. political justice, for majority of Arab intellectuals, political justice was the basis for European achievement and as the primary condition for the Arab renaissance;

b. science, some of Arab intellectuals regarded science as another core point of European power;

c. religion, the question of religious relation with progress/ modernity became an important issue of the first Arab awakening. In addition, the question arose whether Europe was advancing because Christianity supported progress? Or was it on the contrary, the progress of Europe precisely by marginalizing the religion?; and

d. gender, European accusations that the decline of Arabs-Islam because they were discriminating against women had been a trigger for modern Arab intellectuals to rethink women's position in the reality of Muslim society. 
Meanwhile, Abu-Rabi (2006: 9) stated that the important issues discussed by the Arab intellectuals during the Nahda era are as follows:

a. reviving the rational elements of Islamic tradition and finding solutions based on Islamic teachings,

b. embracing the main features of modernity, namely philosophy and science,

c. establishing new institutions and academies of religious education to meet the challenges of modernity,

d. reviving the knowledge of Kalam and,

e. reviving the Islamic languages and beginning to learn foreign languages.

The aforementioned issues became the main subjects of Arab intellectuals during Nahda era. Those whole themes got its portion, depending on the extent to which Arab intellectuals discussed a problem. Any in-depth discussion raised by an intellectual then put him/her into a certain category. For example, if the discussed theme in-depth was about the issue of gender, he/ she will be referred to the pioneer of the first Arab feminists, and so on.

Meanwhile, the defeat of the six-day Arab-Israeli war in 1967 marked a new era of arising a more complex issues of the Arab nation. Post-war defeat became the trigger of the birth of Arab thought which was no longer from the West but the issues that were more focused on internal issues of the Arab World. Boullata (2001, p. 3)suggests that although some writings had been produced during the $20^{\text {th }}$ century and had even been begun in $19^{\text {th }}$ century during the Nahda era, but writings of the Arab intellectuals produced in 1960, 1970, and 1980 were much more urgent and very critical. The works had sad voices about the condition of the Arabs and showed a great desire to fight with modernity. The Arab works, during these eras, reflected the process of change, albeit too abstract or even idealistic.

Some of the works were strongly inspired by the three main trends of Western schools of thought: Anglo-American criticism, 
Western Marxism, and Structuralism and Post-structuralism thought of France (Sharabi, 1992, p. 104). In 1967,it gave a sign of the outpouring of a number of critical Arabic writings about the Arab situation, such as the nuances of philosophy, religion, and literature. Many post-1967 Arab thinkers are forced to rethink some of the major issues that have been taken for granted, even to the stage of the secularization of the text (Abu-Rabi', 2004; Yoyo et al., 2012). The issues raised by the Arabic intellectuals are numerous and some themes are even still correlated to the thoughts generated in the Nahda era. Each intellectual has its own tendency and focus in looking at one problem. Therefore, one particular theme could be discussed in more detail than the other topic.

The aforementioned themes, for example, the position of women in Arab-Muslim societies, generally obtain a larger discussion than the education system. The position of Islam in Arab society receives a very serious concern over humanitarian problems and individual rights. Political issues, especially those related to foreign policy, are much more often a reference to economic issues. The idea of socialism and nationalism in the Arab world attracts more studies than the idea of freedom and democracy. Western imperialism and Zionism, as an obstacle to Arab progress, are analyzed more deeply than the problem of the class system in Arab society (Boullata, 2001).

More specifically, the issues and problems raised by the Arab intellectuals after the Arab defeat as stated by Akhavi (1997, p. 377) are as follows:

a. the methodology of Islamic studies, namely, how to formulate and introduce new methodologies by utilizing Western theories,

b. the search for the basic model for an ideal Muslim society,

c. problem solving of the gap between grass root and elite, 
d. a search for the right model for socio-economic development,

e. the role of the state in the public sphere, and

f. the social base of the Islamic movement.

Slightly different from the thosethemes, Murphy (2002) in Passion for Islam with his modifications, compiled several themes raised by contemporary Arab intellectuals in the following questions:

a. how should the Qur'an be read?

b. what is the most appropriate relationship between religion and the state?

c. what role can Muslim scholars play in the political sphere?

d. who holds the authority in Islam?

e. what is the nature of religious knowledge and how can it be distinguished from religion itself?

f. should Islamic fiqh be modified?

g. can Shari'ah be applied in the modern state format?

h. does "“Islamic secularism”" really exist?

i. if intellectual freedom is a right, how far can a modern Muslim express his confusion of confidence?

j. can criticisms to the essential Islamic doctrine lead someone into apostasy? and who has the authority to punish that?

From the aforementioned issues, the question of how Islam is positioned in the realm of socio-political life remains the main issue of the intellectuals of both generations. This is an important indicator that the position and role of Islam in the socio-political context will remain a major issue for even those who have a tendency towards Liberals, Marxists, or Islamists with different portions.

\section{Sharabi's Intellectual Background}

Sharabi was born in Jaffa, Palestine in 1927 under the British mandate. Therefore, his formative years were constructed 
by colonialism and imperialism. Besides, he experienced as a refugee during the Palestinian struggle in 1936 to 1938 to the Zionist colonial movement. This anger led him to his political activism and intellectual formation. He arrived in the United State in 1947 as young graduate student at the University of Chicago (Davidson, 2005). This Arab alumnus of the University of Chicago did not seem to be popular to the Indonesian academicians and readers on contemporary Arab thought. Sharabi's ideas were rarely studied and researched. This was probably because his intellectual works have not been widely introduced by Indonesian academicians especially by those who graduated from the Middle East universities. Nevertheless, in the contemporary Arab intellectualism, Sharabi's thoughts show its own peculiarities when it comes to the diagnosis and solution to the problems facedby the Arab society. Moreover, at the international level, Sharabi, like Edward W. Said, was known as prominent Arab intellectual and activist who voiced the struggle for the independence of Palestine people (Toensing, 2005).

Sharabi plays an important role in raising awareness and understanding of the Arab world with special emphasis on the Palestinian issues. He devoted of much of his professional life to facilitate public education for his Palestinian people (Toensing, 2005). For 24 years, he worked as an editor of the British Journal of Palestine Studies, published by the Institute for Palestine Studies. In addition, he is the founder of the Center for Contemporary Arab Studies at Georgetown University. Sharabi began his academic career in 1953, teaching history at Georgetown University, USA. When he died on January 13, 2005, he was professor emeritus at European Intellectual History at the university where he worked.

His political activity could be seen from his involvement in the Syrian Socialist Party in 1947 and became the editor of the party's journal. After the Arab defeat of 1967 war and students demonstration movement in 1968, it had a powerful impact on Sharabi's political and intellectual vision. Since then, he turned his back on left politics and began to explore the works of Marx and 
Freud as the foundation for his ideas for the future on the Arab world crisis. Some of Sharabi's works are al-Jamrwa al-Ramad: Dzikrayāt Mutsaqqaf 'Arabi published in 1978, and Shuwar alMādhĩ: Sìrah Dzātiyyah (Portrait of the Past: An Autobiography), published in 1993. However, the most influential work that led him as prominent Arab intellectual is Neo-patriarchy: A Theory of Distorted Change in Arab Society, as most widely read of his intellectual product, published in 1988. A book that attempts to auto-criticism of social conditions of Arab society by emphasizing its neo-patriarchal culture ('The Life of an Arab Intellectual: Dr. Hisham B. Sharabi, 1927 - 2005 - The Jerusalem Fund', no date).

In short, manyof his intellectual works reflect his dissatisfaction with the political and social conditions of the Middle East as well as the struggle for Palestinian people (Davidson, 2005). Therefore, Sharabi was an activist but at the same time as a public and prominent Arab intellectual.

\section{The Genesis of Neo-patriarchy Culture}

Through a critical reading of the reality of the Arab nation, Sharabi saw that, since the end of $19^{\text {th }}$ century (as a reference to the modernism movement in the Arab world) to the Arab defeat of 1967, the Arab world deems it unsuccessful in progressing and trapped in apparent modernism. Sharabi stated that this pseudomodernism or "distorted modernism" is a new form of patriarchal culture. Arabs transformed from an old patriarchal culture to a new patriarchal culture, on which he called neo-patriarchy culture.

Sharabi defined neo-patriarchy as follow:

By neo-patriarchy I refer both to a theoretical formulation as well as to as socio historical reality. In the former sense, neo-patriarchy occupies the space between traditional patriarchy and modernity; in the latter sense, it is a concrete history reality, describing a social entity neither purely traditional nor authentically modern, but a hybrid formation combining both. Neo-patriarchy is a unique product of imperialism and of decolonization, comprising the elements that characterize, in various forms and combinations, the institutions and practices of contemporary life 
in all developing countries, including those of Arab North Africa and the Middle East (Sharabi, 1987: 2)

Sharabi, (1991) in his introduction on The Next Arab Decade: Alternative Future, stated that the failure of the Arabs in adopting western modernism characterized by the birth of four characters of Arab society as follows:

a. Social fragmentation, an attitude in which Arab society constitute their social and organizational relationships based on family, relatives, religious or ethnic relationships.

b. Authoritarian organization, a pattern of leadership characterized by dominance and paternalism that can be seen from the microstructure of a family to the macro structure of a country. In fact, modern society should promote cooperation, recognition, and equality;

c. Absolute paradigm, instead of placing plurality in difference, openness, and other democratic attitudes, Arab society, in fact, generally exhibits absolute awareness in both theoretical, political, and everyday life. Such attitudes stem from the transcendental, metaphysical, and revelatory paradigms;

d. Ritualistic practice, the nature of community life characterized by various ceremonial, custom, and ritual practices. They tend not to be creative and innovative, in contrast to modern society.

For Sharabi, neo-patriarchal society will be more visible when compared to modernity in real practice. For example, the category of "knowledge" which in the context of modernity it is commensurate with the concepts of "thought" and "reason," in neopatriarchal societies,"knowledge" is identical to "myth"/"belief" (religion). Another concept such as "truth" where in the tradition of modernity it is equivalent to "scientific/ironic", while in a patriarchal society, it is synonymous with the concept of "religion/ metaphorical". Likewise with language, in modern society, the nature of language is "analytical" while in neo-patriarchal tradition 
language means "rhetorical"(Sharabi, 1991: 3). In reading and interpretation of al-Qur'an, for example, in the Arab or Muslim world, reading al-Qur'an means "recited" or "repeated." Al-Qur'an is rarely read in a real meaning in order to produce new meaning and interpretation. Besides, interpretation, according to Sharabi, is still monopolized by those who are specialists or religious officials which base their interpretations merely on the sacred text than contextual interpretation (Sharabi, 1988, p. 87).

Thus, the Arab community, according to Sharabi, moves from patriarchy to neo-patriarchy characterized by an attitude of dependence; and neo-patriarchy as a social transformation is nothing but a distorted modernity. The corrupt factor in the neopatriarchal society is not only caused by the patriarchal culture itself (traditionalism), but its historical roots originated from Western imperialism. Dependence, here, is not only caused by aggression and domination, but also more important than that, the economic and military dependence of the Arab community as a peripheral society towards the West as the center.

Suzanne Kassab in her book Contemporary Arab Thought : Cultural Critique in Comparative Perspective (2010: 256) narrated that Sharabi's criticism to the Arab intellectual failure of Nahda Era mainly targeted at three major trends: Muslims reformist, Secular, and Western-Christians. The first two trends, according to Sharabi, are trapped in the defense of Islamization, while the third is due to their social status as minority; their ideas were perceived as too marginal and difficult to break with traditional beliefs. Moreover, the reformists were too focused on how to achieve transformation in Islamic societies while cautioning the dangers of the West rather than criticism. The reformers were busier on the issues faced by the Muslims but unable to criticize Islamic doctrine and thought. Unlike the conservatives who are content with Islamic values and rejecting any external challenges, the Islamic reformers are very much concerned with external issues and seeking to solve them but not in the form of sharp self- criticism. 
While secular Muslims are little free from religious confinement, yet according to Sharabi, they are socially and intellectually trapped in strong religious culture and often subject to social pressure. Secularists avoid religious questions and distance themselves from direct confrontation with deeply rooted beliefs. Thus, just as Muslim reformists, they see Europe as the "other," an agent of modernization but also as a threat to the Islamic world (Kassab, 2010: 265). As with the two mentioned groups, the scholars of Christian community have a sharper tendency of thought and are able to adapt well with Europe. This is due to their educational background following European model. As a minority, they are more interested in secular views about history and society and less interested in defensive arguments against issues related to the West. Because of their social position, Christian intellectuals, according to Sharabi, always guard themselves by maintaining more general statements and arguments to avoid confrontation with Muslim majority. Therefore, they do not really take a firm stance in the form of sharp criticism, as the main condition of the renaissance, nahdhah (Kassab, 2010: 266).

From the various modes of thought that existed in the Arab world especially during 1980-1990s, Islamic fundamentalism or Islamism, according to Sharabi, was dominating compared to other modes of thought. However, the future of the Arabs cannot be left to this group. For Sharabi, there is no guarantee that the Islamist groups will provide fundamental changes in the structure of neopatriarchal society. So, if this group wins the arena in political contestation, then the essence of the neo-patriarchal society will still exist (Tamadonfar, no date; Sharabi, 1988). Then, what kind of solution did Sharabi offer for the Arab society to be detached from neo-patriarchal culture and achieve complete modernity? While there was a possibility of revolution, but it is impossible to be conducted during his time. According to him, there is no guarantee when the authoritarian regime isoverthrown, justice and democracy can be achieved. Then the urgent and long-term solution that must be done is by criticizing and deconstructing 
the old neo-patriarchal conception of liberation (Sharabi, 1988: 148-150).

\section{Some Solutions}

Criticism for Sharabi is a vital need that not only pursues a "critical discourse" that can generate self-critical awareness, but far more important than that is to deconstruct neo-patriarchal consciousness that has bounded thought and action for more than a century. Criticism for Sharabi is a key condition in the process of overthrowing neo-patriarchal discourse and paving the way for modernity (Sharabi, 1988: 151). By studying various schools of thought and politics that ever conceived and implemented in the Arab world such as Pan-Islamism and Pan-Arabism, and parliamentary democracy controlled only by the bourgeoisie, Sharabi proposed that particular concepts such as democracy, unity, social justice, and others social and political terminologies should be reinterpreted and redefined again and again by looking at the new existing realities. This possibility can only be done by starting from the structural and institutional level of the status quo, not through a utopian vision. This pressure should be conducted by formal and legal approach and not by violence action or revolution. The younger generation of Arabs should be introduced in these smooth ways and not through the repression and violence actions such as introduced by the Arab authoritarian regimes (Sharabi, 1988: 152).

Therefore, Sharabi stated that there are four mains areas where new critique should be addressed: on linguistic, interpretative, ideological, and social level. On linguistic level, the new critique should transform the vocabulary of neo-patriarchy discourse into a new terminology and a new language; on interpretative level it tries to eliminate dominant interpretations and to build new perspective in order to displace limiting horizon of neo-patriarchy understanding. On ideological level, it aims at deconstructing all existing ideologies and replacing it with more open ideological space. It tries to de-legitimate theological 
authority and political power. To implement this project, language and linguistic plays important role on overcoming rhetorical and ideological of naïve interpretation (Sharabi, 1987).

Sharabi further asserts that in order to make an update in the radical democratic paradigm, he proposes two inter-related methods that are critical and contestation. Critical attitudes performed by using diverse disciplines and approaches and excluding any occupying hegemonic and privileged positions. In the other way, contestation method is a dialogical and non-violent approach; it takes critical attitude of society as a basis for struggle. The action, according to Sharabi, will involve various elements of the organizations, individuals such as intellectuals, professional worker groups, students and women's organizations, as well as various political parties. In essence, all elements of society must be involved in the movement and should pay attention to the condition and reality of each country. In addition, some Arab countries allow acceptance of change, but there are also leaders who resist change. In the last model, considerable violence may occur (Sharabi, 1988: 153-154).

Therefore, Sharabi firmly stated that the aim of the struggle is no longer sectarian and not tied to a particular ideology but must be based on universal values and recognized by the majority as appropriate and politically feasible. The general and specific objectives are human rights and political struggles: human rights derived from the Declaration of Human Rights (specifically translated into the Arab Organization for Human Rights); and political rights based on the constitution and provisions that apply specifically in each of the Arab countries. Meanwhile, the specific objectives, according to Sharabi, should be the establishment of a nation and Pan-Arab racial vehicle for social and political purposes. The most potent social groups that can make radical democratic changes are professional associations (academia, medical and law), trade unions, farmer groups, women's and student organizations, and other autonomous organizations (Sharabi 1988: 154). 
All of the aforementioned proposals are possible considerations by looking at the conditions prevailing at the time. According to him, the proposal is not an agenda or program that must be done. Such activities or agendas are only possible when all elements of society are willing to work together in a concrete situation. Sharabi acknowledged that the Arab World is a place that is socially and politically very complex and difficult. Nevertheless, the optimism for the better future of the Arab world should be given as priority in order to dismiss neo-patriarchal culture and accept real modernity. In short, the pessimism of what the intellectuals think must not abolish the optimism of one's will (Sharabi, 1988: 155).

\section{Conclusion}

The social and political conditions analyzed by Sharabi was a critical period. The Arab defeat of 1967 war shocked and destroyed any Arab intellectual projects even political dreams of most the Arab intellectuals. Socio-political portraits during 1970s and 1980s were dominated by the clash among competing ideologies. This is certainly much different from the recent sociopolitical conditions. Nevertheless, the urgency of Sharabi's ideas lie on his theory of neo-patriarchal culture giving a picture of pseudo-modernity that takes place in various spheres of the Arab society. Instead of achieving modernity, just as it did in Europe, the Arabs were trapped in a new form of patriarchy of social, political, religious and economic life that was still confined and dependent on the West-mainly in economic and military fields. This fact can be seen in geo-cultural and political developments taking place in the Middle East to this day where most of Arab countries have a strong dependence on military products from the West and even high foreign debt as experienced by the Egyptian regime nowadays.

Besides, religious tensions and conflicts among Muslims in the Arab world reflected that "neo-patriarchy" in religious life have led into bloody conflict. Religious doctrines are used just to 
legitimate brutal actions. This fatalistic interpretation of religious texts as stated by Sharabiare very dominant. Therefore, reading religious texts in hermeneutical way should be elaborated in response to recent situation.

However, the ideas of Sharabi in general as stated by Boullata (2001: 128) are less applicable in all parts of the Arab world in particular and Third world in general. What we probably can do is to look at Sharabi's neo-patriarchy concept as an analytical concept to look at certain sociocultural conditions by seeing that each region in the Arab World has different neo-patriarchal charges. Since neo-patriarchy is a product of imperialism, it is the existence of a synthesis between tradition and modernity. 


\section{References}

Abu-Rabi, I. M. (2006) Contemporary Islamic Intellectual History: A Theoretical Perspective. Majlis Ugama Islam Singapura.

Abu-Rabi', I. M. (2004) Contemporary Arab thought: Studies in post-1967 Arab Intellectual History. London: Pluto Press.

Akhavi, S. (1997) 'The Dialectic in Contemporary Egyptian Social Thought: the Scripturalist and Modernist Discourses of Sayyid Qutb and Hasan Hanafi', International Journal of Middle East Studies. Cambridge University Press, 29(3), pp. 377-401.

Boullata, I. J. (2001) Dekonstruksi Tradisi: Gelegar Pemikiran Arab Islam. Yogyakarta: LKiS.

Davidson, L. (2005) 'Remembering Hisham Sharabi (1927-2005)', Journal of Palestine Studies. [University of California Press, Institute for Palestine Studies], 34(3), pp. 57-64. doi: 10.1525/jps.2005.34.3.57.

Hourani, A. (1962) Arabic Thought in the Liberal Age. London: Oxford University Press.

Kassab, E. S. (2010) Contemporary Arab thought : Cultural Critique in Comparative Perspective. New York: Columbia University Press.

Murphy, C. (2002) Passion for Islam: Shaping the Modern Middle East: The Egyptian Experience. New York: Scribner.

Sharabi, H. (1987) 'Cultural Critics of Contemporary Arab Society', Arab Studies Quarterly. Pluto Journals, 9(1), pp. 1-19. Available at: http://www.jstor.org/stable/41857915.

Sharabi, H. (1988) Neopatriarchy: A Theory of Distorted Change in Arab Societies. New York: Oxford University Press.

Sharabi, H. (1991) 'Introduction: Patriarchy and Dependency and the Future of Arab Society', in The Next Arab Decade: 
Alternative Futures. London: Mansell Publishing Limited, pp. 1-8.

Sharabi, H. (1992) Neopatriarchy: A theory of Distorted Change in Arab Society. Oxford University Press.

Tamadonfar, M. (no date) 'No Title', International Journal of Middle East Studies. Edited by H. Sharabi. Cambridge University Press, 26(1), pp. 170-171.

The Life of an Arab Intellectual: Dr. Hisham B. Sharabi, 1927 2005 - The Jerusalem Fund' (no date). Available at: http:// www.thejerusalemfund.org/4079/the-life-of-an-arabintellectual-dr-hisham-b-sharabi-1927-2005 (Accessed: 20 July 2017).

Toensing, C. (2005) 'Hisham Sharabi', Middle East Report. Middle East Research and Information Project (MERIP), (234), p. 2. Available at: http://www.jstor.org/stable/1559359.

Yoyo, Y. et al. (2012) 'Tren Pemikiran Intelektual Muslim Kontemporer di Timur Tengah Pasca-Difitisme 1967', Kawistara. Graduate School, Universitas Gadjah Mada, 2(3), pp. 225-328. 
|Yoyo 